\title{
34. DATA REPORT: GEOCHEMICAL WELL LOGS THROUGH CENOZOIC AND MESOZOIC SEDIMENTS FROM SITES 800, 801, AND 802 ${ }^{1}$
}

\author{
Elizabeth Lewis Pratson, ${ }^{2}$ Cristina Brogalia, ${ }^{2}$ Alain Molinie, ${ }^{2}$ and Lewis Abrams ${ }^{3}$
}

\begin{abstract}
Geochemical well logs were obtained in sediment at Sites 800, 801, and 802 of Ocean Drilling Program Leg 129. Corrections have been applied to the logs to account for variations in hole size, drilling-fluid composition, and drill-pipe attenuation. Oxide and calcium carbonate weight percentages have been calculated from the processed logs and are compared with the available measurements of core. $\mathrm{Log}$-derived $\mathrm{CaCO}_{3}$ measurements correlate well with shipboard $\mathrm{CaCO}_{3}$ core measurements from $\mathrm{Holes}$ $800 \mathrm{~A}$ and $802 \mathrm{~A}$. Log measurements are compared with X-ray fluorescence measurements from Holes $800 \mathrm{~A}$ and $801 \mathrm{~B}$. Because of selective sampling from silica-rich beds, discrepancies between log and core data occur. The silica logs show values higher overall than those of the core measurements; the aluminum logs show values lower overall.
\end{abstract}

\section{INTRODUCTION}

Drilling on Leg 129 penetrated Mesozoic sediments and volcanic basement from the Pigafetta and East Mariana basins, thereby recovering rocks of the oldest remaining in situ oceanic crust. Three sites were drilled on Leg 129: 800 in the northern Pigafetta Basin, 801 in the central Pigafetta Basin, and 802 in the Mariana Basin (Fig. 1).

The geochemical tool string, which measures the major elements of a formation at intervals of $0.1524 \mathrm{~m}$, recorded data at each site. The geochemical data provide an invaluable record of the rock chemistry for the sites of Leg 129, where core recovery was sporadic.

This report describes the hole conditions and logging operations at each site, presents the basic principles of the geochemical tool string, explains the data processing techniques, and compares the processed natural gamma-ray and oxide/calcium carbonate measurements estimated from the logs with available core measurements.

\section{DATA ACQUISITION}

\section{Site 800}

The objective of drilling at this site was to recover, with a single drill bit, as complete a section of Mesozoic sediments and basement as possible. Hole $800 \mathrm{~A}$ was drilled to $544.5 \mathrm{mbsf}$. Recovery was good in the clay of the upper $30 \mathrm{~m}$ of hole but became poor $(<7 \%)$ in the chert, porcellanite, and limestone units from 30 to $228.6 \mathrm{mbsf}$. Recovery improved in the volcaniclastic sediments from 228 to 498 mbsf, after which depth doleritic basalts were encountered. The basalt was cored to 544.5 mbsf. Hole conditions prompted the decision to make a wiper trip and ream the hole. During the wiper trip, however, swelling clay bridges prevented the BHA (bottom hole assembly) from passing below 335 mbsf. The hole was then conditioned with $2.5 \% \mathrm{KCl}$ to stabilize the clay. For each logging run, the pipe was pulled to $70 \mathrm{mbsf}$, then raised to 50 mbsf while logging uphole (Shipboard Scientific Party, 1990a).

Three logging passes were completed at Hole $800 \mathrm{~A}$; however, because of the obstruction at $335 \mathrm{mbsf}$, logs were recorded only in the upper sediment section of the hole. The first logging pass was with the "quad-combo" (consisting of the telemetry, long-spaced sonic, lith-

\footnotetext{
'Larson, R. L., Lancelot, Y., et al., 1992. Proc. ODP, Sci. Results, 129: College Station, TX (Ocean Drilling Program)

${ }^{2}$ Borehole Research Group, Lamont-Doherty Geological Observatory of Columbia University, Palisades, NY 10964, U.S.A

${ }^{3}$ Graduate School of Oceanography, University of Rhode Island, Narragansett, RI, 02882-1197, U.S.A.
}

odensity, natural gamma-ray, dual-induction resistivity, and Lamont temperature tools), which recorded data from 50.6 to $312.3 \mathrm{mbsf}$. The second pass was with the geochemical logging string, which recorded data from 43.12 to 313.1 mbsf. The third pass was with the formation microscanner (FMS, trademark of Schlumberger), which recorded data from 50.6 to $312.3 \mathrm{mbsf}$

\section{Site 801}

The Leg 129 objective of recovering the oldest rocks remaining in the Pacific was achieved at this site, making this the first Deep Sea Drilling Project/Ocean Drilling Program (DSDP/ODP) drill site ever to recover Jurassic sediments or crust from this part of the world. Hole 801A was rotary cored to $194 \mathrm{mbsf}$. Because the hole deviated up to $8^{\circ}$ from vertical, it was terminated.

Hole $801 \mathrm{~B}$ was spudded $15 \mathrm{~m}$ east and $46 \mathrm{~m}$ south of Hole $801 \mathrm{~A}$. The hole was drilled to a total depth of 194 mbsf, where a deviation of $2.5^{\circ}$ was measured. After this depth the hole was cored to $511 \mathrm{mbsf}$, recovering basalt interbedded with chert from 461 to $483 \mathrm{mbsf}$ and solid basalt from 483 to 511 mbsf. Drilling was terminated so that the sedimentary sequence could be logged while the hole was still in good condition. To prepare for logging, a complete wiper trip was made, and salt water was circulated. In order to cover the hole disruptions in the chert zone, pipe was raised to $78 \mathrm{mbsf}$ and then pulled up to approximately $64 \mathrm{mbsf}$ while the tools were run uphole.

The same three tool strings that were run in Hole 800A were also run in Hole 801B. The first string to record logs was the quad combo, run from 445.7 to $54.4 \mathrm{mbsf}$. During the logging with the quad-combo it was discovered that the wireline heave compensator (WHC) had failed while under the full tension of the tool. Two complete passes of the FMS tool string were then completed through the open hole interval from 44.6 to $472 \mathrm{mbsf}$ during which the WHC was working. Finally the geochemical tool string was run. Logs were recorded over the interval from 54 to $448 \mathrm{mbsf}$, during which the WHC again failed.

\section{Site $\mathbf{8 0 2}$}

Hole $802 \mathrm{~A}$ was cored to a depth of $560 \mathrm{mbsf}, 51 \mathrm{~m}$ of which was in basalt. Recovery through the hole was moderate, ranging from $0 \%$ to $80 \%$. The hole appeared to be in good condition and was swept with freshwater bentonite mud, which was then displaced by seawater. At this point coring was terminated due to the discovery of $43 \mathrm{~m}$ of fill at the bottom of the hole. In preparation for logging, the core bit was dropped, and the pipe raised to $50 \mathrm{mbsf}$. No subsequent wiper trip was made because of the hole instability encountered during the previous wiper trip. 


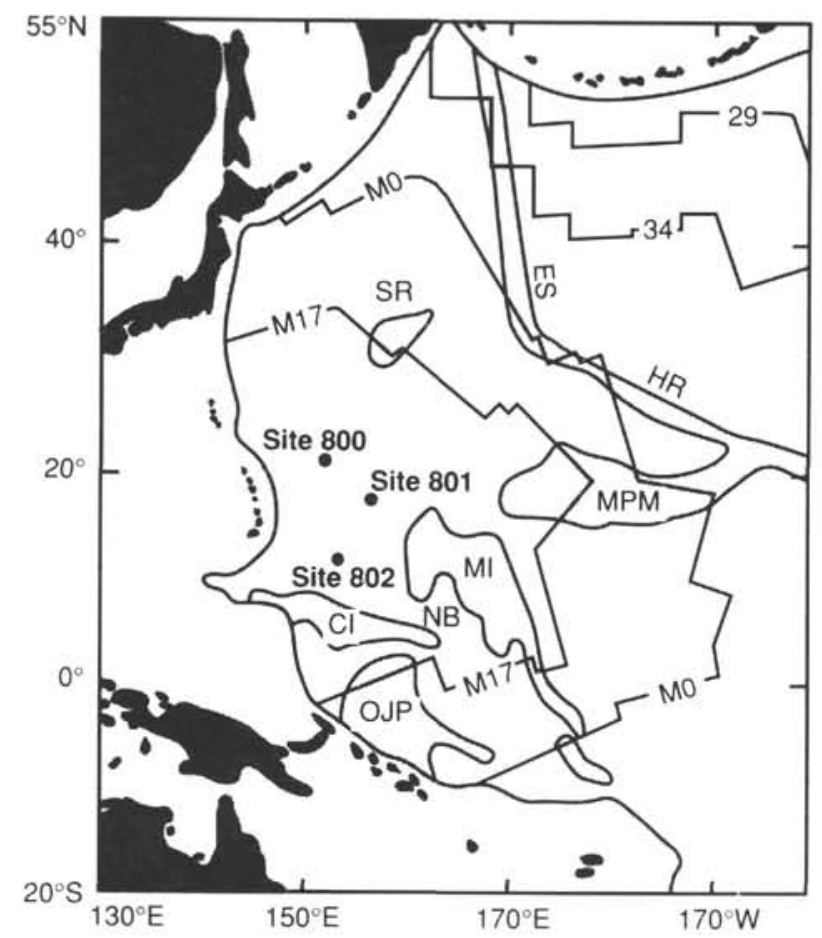

Figure 1. Location of Leg 129 Sites 800,801 and 802 in the central western Pacific Ocean (after Shipboard Scientific Party, 1990a). Shaded areas represent areas of volcanic edifices with thickened crustal sections, as well as the younger areas beyond the Pacific subduction zones. Abbreviations are as follows: Caroline Islands (CI), Ontong Java Plateau (OJP), Marshall Islands (MI), Nauru Basin, (NB), Mid Pacific Mountains (MPM), Shatsky Rise (SR), Hawaiian Ridge (HR), and Emperor Seamounts (ES).

The same three standard logging tool strings that were run in Holes $800 \mathrm{~A}$ and $801 \mathrm{~B}$ were run in Hole $802 \mathrm{~A}$. The first logging string, the quad-combo, encountered a bridge at $103 \mathrm{mbsf}$. The tool was pulled up, and pipe was lowered to $127 \mathrm{mbsf}$ to cover the clay zone causing the swelling. The string was run a second time; however, another bridge was encountered at $323 \mathrm{mbsf}$. Log data were therefore obtained only from 323 to 108 mbsf. The geochemical tool string and the formation microscanner were also run over the same interval.

\section{GEOCHEMICAL TOOL STRING}

The geochemical logging tool string (GLT) consists of four logging tools: the natural gamma-ray tool (NGT), the compensated neutron tool (CNT), the aluminum activation clay tool (AACT), and the gamma-ray spectrometry tool (GST) (GLT, NGT, CNT, AACT, and GST are trademarks of Schlumberger; Fig. 2). The natural gamma-ray tool is located at the top of the tool string, so that it can measure the naturally occurring radionuclides, thorium $(\mathrm{Th})$, uranium $(\mathrm{U})$, and potassium $(\mathrm{K})$, before the formation is irradiated by the nuclear sources contained in the lower tools. Below the natural gamma-ray tool is the compensated neutron tool, which carries low-energy californium- $252\left({ }^{252} \mathrm{Cf}\right)$ to activate the $\mathrm{Al}$ atoms in the formation. The aluminum activation clay tool, a modified NGT, is located below the ${ }^{252} \mathrm{Cf}$ source, measuring the activated gamma rays in the formation. By combining the AACT measurement with the previous NGT measurement, the background radiation is subtracted out and a reading of formation Al is obtained (Scott and Smith, 1973). The gammaray spectrometry tool, at the base of the string, carries a pulsed neutron generator to induce capture gamma-ray reactions in the borehole and formation and an $\mathrm{NaI}(\mathrm{Tl})$ scintillation detector to measure the spectrum of gamma rays generated by neutron capture reactions. Because each of the elements in the formation is characterized by a unique spectral signature, it is possible to derive the contribution (or yield) of each of the major elements silicon ( $\mathrm{Si})$, iron $(\mathrm{Fe})$, calcium $(\mathrm{Ca})$, titanium (Ti), sulfur (S), gadolinium (Gd), and potassium (K) to the measured spectrum and, in turn, to estimate the relative abundance of each in the formation. The GST also measures the hydrogen $(\mathrm{H})$ and chlorine $(\mathrm{Cl})$ in the borehole and formation, but these elements are not used for determining rock geochemistry.

The only major rock-forming elements not measured by the geochemical tool string are magnesium $(\mathrm{Mg})$ and sodium $(\mathrm{Na})$; the neutron-capture cross sections of these elements are too small relative to their typical abundances for the tool string to detect them. A rough estimate of $\mathrm{Mg}+\mathrm{Na}$ can be made by using the photoelectric factor (PEF), measured by the lithodensity tool. This measured PEF is compared with a calculated PEF (a summation of the PEF from all the measured elements). The separation between the measured and calculated PEFs is, in theory, attributable to any element left over in the formation (i.e., $\mathrm{Mg}$ and $\mathrm{Na}$ ). Further explanation of this technique is found in Hertzog et al. (1987). This calculation was attempted, but it yielded an unlikely straight zero $\mathrm{Mg}+\mathrm{Na}$ curve with scattered spikes. The inclusion of this unreliable $\mathrm{Mg}+\mathrm{Na}$ curve in the normalization with the other elements would have induced noise into all the other elements; therefore, it was not included.

\section{DATA REDUCTION}

The well-log data from the Schlumberger tools are transmitted digitally up a wireline and are recorded and processed on the JOIDES Resolution in the Schlumberger Cyber Service Unit (CSU). The results from the CSU are made available as "field logs" for initial shipboard interpretation. Subsequent reprocessing is necessary to correct the data for the effects of fluids added to the well, logging speed, and pipe interference. Processing of the spectrometry data is required to transform the relative elemental yields into oxide weight fractions.

The processing is performed with a set of log-interpretation programs written by Schlumberger. The steps are summarized below.

\section{Step 1. Reconstruction of relative elemental yields from recorded spectral data}

This first processing step uses a weighted, least-squares method to compare the measured spectra from the geochemical spectrometry tool with a series of standard spectra to determine the relative contribution (or yield) of each element. Whereas six elemental standards ( $\mathrm{Si}, \mathrm{Fe}, \mathrm{Ca}, \mathrm{S}, \mathrm{Cl}$, and $\mathrm{H}$ ) are used to produce the shipboard yields, three additional standards ( $\mathrm{Ti}, \mathrm{Gd}$, and $\mathrm{K}$ ) can be included in the shore-based processing to improve the fit of the spectral standards to the measured spectra (Grau and Schweitzer, 1989). These additional three standards cannot be included on the ship because of limited processing power. Although these additional elements often appear in the formation in very low concentrations, they can make a large contribution to the measured spectra because they have large neutroncapture cross sections. For example, the capture cross section of $\mathrm{Gd}$ is 49,000 barns; that of $\mathrm{Si}$ is 0.16 barns (Hertzog et al., 1987); therefore, although occurring in very small abundances in the formation, $\mathrm{Gd}$ is included in the calculation of a best fit between the measured and the standard spectra. This best-fit analysis was performed for the elements in each of the logged holes to include spectral standards for $\mathrm{Si}, \mathrm{Ca}, \mathrm{Fe}, \mathrm{Ti}, \mathrm{Gd}, \mathrm{H}$, and $\mathrm{Cl}$. The spectral standards for $\mathrm{K}$ and $\mathrm{S}$ were not used because these two elements existed in concentrations below the resolution of the tool, and including them would significantly increase the noise level of all the other yields. A straight, seven-point smoothing filter was applied to all the yields in both holes to reduce the noise in the data. The Ca yield was divided by two to correct for $\mathrm{Cl}$ interference, a routine typically done when logging in saline fluids (J. A. Grau, pers, comm., 1988). 
TCCB

NGT

AACT

CNT-G

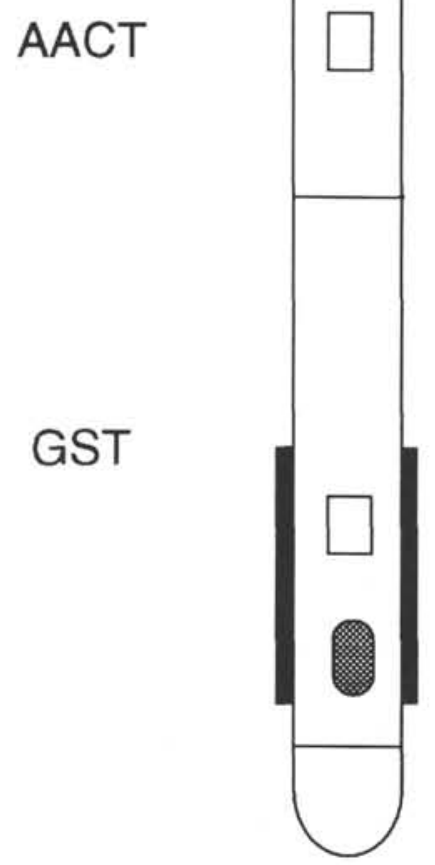

Telemetry cartridge

Natural gamma-ray tool: measures naturally radioactive elements thorium, uranium, and potassium.

Dual-porosity compensated neutron tool: Measures neutron porosity in the thermal and epithermal energy ranges.

Thermal detectors

Californium 252 source

Epithermal detectors

Aluminum activation clay tool: Measures aluminum activation and natural count rates as it passes the formation activated by Californium 252 .

Gamma-ray spectrometry tool: Measures concentration of calcium, silicon, iron, sulfur, gadolinium, titanium, hydrogen, chlorine, and formation thermal neutron capture cross-section.

$\longleftarrow$ Boron sleeve - 3.75 in.

— Neutron accelerator

Figure 2. Schematic drawing of the geochemical logging string used by the Ocean Drilling Program. 


\section{Step 2. Depth shifting}

Geochemical processing involves the integration of data from the different tool strings. Consequently it is important that all the data are depth-correlated to one reference logging run. An NGT is run on each of the logging tool strings which is used to provide a spectral gamma ray curve with which to correlate each of the logging runs. In both Holes $800 \mathrm{~A}$ and $801 \mathrm{~B}$, the NGT was run out of sequence on the quad-combo tool string. The NGT is ordinarily located at the top of the tool in order to measure the natural gamma rays before the formation has been activated. At these two sites, however, in the quad-combo string, the NGT was located below the density tool and therefore the formation had been activated by the density cesium source before the NGT could make any measurement, thus causing the readings to be too high. Despite this error in the tool string configuration, however, the gamma ray logs from the quad-combo are still valid as qualitative indicators of natural radioactivity in the formation and as a reference run for depth shifting.

A reference run is chosen based on cable tension (the logging run with the least amount of cable sticking) and cable speed (tools run at faster speeds are less likely to stick). The depth shifting procedure involves picking a number of reference points and then using a program which stretches and squeezes the matching logging run to fit the reference logging run.

The quad-combo was chosen as the reference run in Hole $800 \mathrm{~A}$. The FMS was chosen as the reference run in Hole 801B, as this was the only run during which the WHC was working. The GLT was used as the reference run in Hole $802 \mathrm{~A}$, again because the WHC was working during this run but not during the quad-combo logging run.

\section{Step 3. Calculation of total radioactivity and $T h, U$, and $K$ concentrations}

The third processing routine calculates the total natural gamma radiation in the formation as well as concentrations of Th, $\mathrm{U}$, and $\mathrm{K}$, using the counts in five spectral windows from the NGT (Lock and Hoyer, 1971). This routine resembles shipboard processing, except that corrections for hole-size changes are made in the shore-based processing of these curves. A Kalman filtering (Ruckebusch, 1983) is used at sea to minimize the statistical uncertainties in the logs, which would otherwise create erroneous negative readings and anti-correlations (especially between $\mathrm{Th}$ and $\mathrm{U}$ ). An alpha filter, recently introduced by Schlumberger for shore-based processing, was used here. This filter strongly filters the raw spectral curves but keeps the total gamma-ray curve unsmoothed before calculating out the Th, U, and K (Charles Flaum, pers. comm., 1988). At each depth, level calculations and corrections also were made for $\mathrm{K}$ contained in the mud. The $\mathrm{K}$ correction is particularly useful where $\mathrm{K}$-bearing muds are routinely added to the hole; however, because of dispersion it is difficult to know exactly how much $\mathrm{K}$ is actually in the borehole. The outputs of this program are $\mathrm{K}$ (wet wt \%), U (ppm), and Th (ppm), along with a total gamma-ray curve and a computed gamma-ray curve (CGR; total gamma ray minus $\mathrm{U}$ contribution).

\section{Step 4. Calculation of Al concentration}

The fourth processing routine calculates an $\mathrm{Al}$ curve using four energy windows, while concurrently correcting for natural activity, borehole-fluid neutron-capture cross section, formation neutron-capture cross section, formation slowing-down length, and borehole size. Porosity and density logs are needed in this routine to convert the wet-weight percentages of $\mathrm{K}$ and $\mathrm{Al}$ curves to dry-weight percentages. Because the density logs in each of the three holes compared well with shipboard core measurements, and because no porosity log was recorded, a porosity curve was derived from the density log using the equation

$$
P H I T=(\text { RHOM }- \text { RHOB }) /(\text { RHOM }- \text { RHOF }),
$$

where

$P H I T=$ percentage porosity,

RHOM = matrix density, obtained from core measurements in $\mathrm{g} / \mathrm{cm}^{3}$, $R H O B=$ bulk density from the log in $\mathrm{g} / \mathrm{cm}^{3}$,

RHOF $=$ density of fluid $=1.05 \mathrm{~g} / \mathrm{cm}^{3}$.

A correction is also made for $\mathrm{Si}$ interference with $\mathrm{Al}$; the ${ }^{252} \mathrm{Cf}$ source activates the $\mathrm{Si}$, producing the aluminum isotope $\mathrm{Al}^{28}$ (Hertzog et al., 1987). The program uses the $\mathrm{Si}$ yield from the gamma-ray spectrometry tool to determine the Si background correction. The program outputs dry-weight percentages of $\mathrm{Al}$ and $\mathrm{K}$, which are used in the calculation and normalization of the remaining elements.

\section{Step 5. Normalization of elemental yields from the GST to calculate the elemental weight fractions}

This routine combines the dry weight percentages of $\mathrm{Al}$ and $\mathrm{K}$ with the reconstructed yields to obtain dry weight percentages of the GST elements using the relationship

$$
W t_{i}=F Y / S_{i},
$$

where

$W t_{i}=$ absolute elemental concentration,

$F=$ normalization factor,

$Y_{i}=$ relative elemental yield, and

$S_{i}=$ tool spectral sensitivity.

The normalization factor, $F$, is a calibration factor determined at each depth from a closure argument to account for the number of neutrons captured by a specific concentration of rock elements. Because the sum of oxides in a rock is $100 \%, F$ is given by

$$
F\left(\sum_{i X i} Y / S_{i}\right)+X_{\mathrm{K}} W t_{\mathrm{K}}+X_{\mathrm{Al}} W t_{\mathrm{Al}}=100,
$$

where

$$
\begin{aligned}
& X_{i}=\text { dry wt } \% \text { of oxide or carbonate dry wt } \% \text { of element } i, \\
& Y_{i}=\text { fraction of spectra attributed to element } i, \\
& S_{i}=\text { sensitivity factor, } \\
& X_{\mathrm{K}}=\text { dry wt } \% \text { of oxide of element } \mathrm{K} \text { dry wt } \% \text { of } \mathrm{K}, \\
& W t_{\mathrm{K}}=\text { dry wt } \% \text { of } \mathrm{K} \text {, } \\
& X \mathrm{v}_{\mathrm{Al}}=\text { dry wt } \% \text { of oxide of element Al dry wt } \% \text { of Al, and } \\
& W t_{\mathrm{Al}}=\text { dry wt } \% \text { of } \mathrm{Al} \text {. }
\end{aligned}
$$

The sensitivity factor, $S_{i}$, is a tool constant measured in the laboratory, which depends on the capture cross section, gamma-ray production, and detection probabilities of each element measured by the GST (Hertzog et al., 1987).

The value $X_{i}$ accounts for the $\mathrm{C}$ and $\mathrm{O}$ associated with each element. Table 1 lists the oxide factors used in this calculation. All the measured elements associate with $\mathrm{C}$ and $\mathrm{O}$ in a constant ratio in these lithologies, except for $\mathrm{Ca}$, which associates with $\mathrm{C}$ and $\mathrm{O}$ in two ways: $\mathrm{CaCO}_{3}$ or $\mathrm{CaO}$ (Table 1). In order to convert the measured yields to elements/oxides, a dominant form of Ca must be assumed. The assumption is based both on the dominant lithology described in the cores and on the log signatures. In Hole $800 \mathrm{~A}$ from 48.5 to $81 \mathrm{mbsf}$, the $\mathrm{CaO}$ fraction was assumed; from 81 to $219.5 \mathrm{mbsf}, \mathrm{CaCO}_{3}$ was assumed; and from $219.5 \mathrm{mbsf}$ to the bottom of this logged interval ( $317 \mathrm{mbsf}), \mathrm{CaO}$ was assumed. Throughout Hole $801 \mathrm{~B}, \mathrm{CaO}$ was assumed. $\mathrm{CaO}$ was assumed above $218 \mathrm{mbsf}$, and $\mathrm{CaCO}_{3}$ was assumed below this depth to total depth in Hole 802A.

\section{Step 6. Calculation of oxide percentages}

The sixth and final routine simply multiplies the percentage of each element by its associated oxide factor, using the same oxide factors as were used in the previous step (Table 1). 


\section{COMPARISON OF GEOCHEMICAL LOGS TO CORE}

\section{Site 800}

The processed natural gamma-ray curves from the quad-combo at Hole 800A are shown in Figure 3 and compared to lithostratigraphic units described from core (Shipboard Scientific Party, 1990a). The chert and porcellanite of lithostratigraphic Unit II are distinguished from the chert and limestone of Unit III by higher total gamma-ray curve (SGR) values in Unit II, primarily resulting from elevated U content within Unit II. The SGR values are lower in Unit III. Total gamma-ray values increase in Unit IV, attributable to higher $\mathrm{K}$ in the volcaniclastics of this unit.

Figure 4 displays the oxide weight fractions estimated from the logs at Hole $800 \mathrm{~A}$, along with calculated statistical uncertainties (plus and minus one standard deviation) of each element (Grau et al., 1990; Schweitzer et al., 1988). This error is strongly related to the normalization factor which is calculated at each depth (Equation 3). The normalization factor is displayed along with oxide measurements to the right. A lower normalization factor represents better counting for comparison as solid circles. XRF analyses were obtained from the work of Karl and Karpoff (this volume) and displayed as diamonds. The samples taken for analysis were biased, due to the poor core recovery encountered through most of the logged interval, which resulted in retrieval of only the more lithified sediments, and to the preferential sampling of silica-rich intervals for XRF analysis (Fisher et al., this volume). The silica log values are therefore slightly low relative to core values, while the $\mathrm{Al} \log$ values are high.

The chert and porcellanite of Unit II are distinguished on the oxide weight fraction logs by their high silica content. The mineralogical trends within Unit III range from higher quartz and opal-CT contents in the upper part, higher calcite content in the middle interval, and higher clay content in the lower parts of the unit (Shipboard Scientific Party, 1990a). The geochemical logs show these mineralogical trends in even more detail. The logs indicate that the carbonate content does not increase continuously, as was interpreted by core measurements (Shipboard Scientific Party, 1990a); it instead shows two separate zones of increase within the middle part of this unit. The higher clay content at the bottom of the unit (197 to $221 \mathrm{mbsf}$ ) is indicated by elevated log values of $\mathrm{Al}_{2} \mathrm{O}_{3}, \mathrm{~K}_{2} \mathrm{O}$, and $\mathrm{FeO} *\left(\mathrm{Fe}_{2} \mathrm{O}_{3}+\mathrm{FeO}\right)$, which mirrors a decrease in carbonate content.

The volcaniclastic lithology of Unit IV is distinguished on the logs by an increase in elements associated with clay and volcanic sand ( $\mathrm{FeO} *, \mathrm{Al}_{2} \mathrm{O}_{3}, \mathrm{~K}_{2} \mathrm{O}$, and $\mathrm{TiO}_{2}$ ). The geochemical logs show two intervals of higher clay content ( 221 to $259 \mathrm{mbsf}$, and $286 \mathrm{mbsf}$ to the bottom of the logged interval).

\section{Site 801}

The processed natural gamma-ray logs from Hole 801B (Figure 5) come from the geochemical tool string. These natural gamma-ray logs display distinctly different characters within each of the lithologic units. The chert and porcellanite of lithostratigraphic Unit II have a low total gamma-ray content relative to the rest of the hole. The total gamma-ray content increases sharply at the boundary of Units II and III and remains high with some variability. This increase in the gamma-ray log results from increased $\mathrm{K}$ content associated with the volcanic turbidite minerals. The total gamma-ray content remains high in Unit IV; however, the CGR decreases because of the increase in $\mathrm{U}$ content and the decrease in $\mathrm{K}$ content.

The oxide weight fractions along with uncertainties for Hole 801B are shown in Figure 6. XRF analyses (Karl and Karpoff, this volume) are displayed as diamonds for comparison. Discrepancies exist between the core and log values, particularly between those for $\mathrm{Al}$. The discrepancies are attributed to both selective sampling of silica-rich areas and to possible mud caking of Al-bearing clays along the
Table 1. Oxide factors used in normalizing elements to $100 \%$ and converting elements to oxides.

\begin{tabular}{lll}
\hline Element & Oxide/carbonate & Conversion factor \\
\hline $\mathrm{Si}$ & $\mathrm{SiO}_{2}$ & 2.139 \\
$\mathrm{Ca}$ & $\mathrm{CaO}$ & 1.399 \\
& $\mathrm{CaCO}_{3}$ & 2.497 \\
$\mathrm{Fe}$ & $\mathrm{FeO}^{*}($ total Fe) & 1.358 \\
$\mathrm{~K}$ & $\mathrm{~K}_{2} \mathrm{O}$ & 1.205 \\
$\mathrm{Ti}$ & $\mathrm{TiO}_{2}$ & 1.668 \\
$\mathrm{Al}$ & $\mathrm{Al}_{2} \mathrm{O}_{3}$ & 1.899 \\
\hline
\end{tabular}

borehole walls which would cause a higher $\mathrm{Al}$ reading, particularly in zones of hole washout.

The chert and porcellanite of Unit II are seen on the geochemical logs to have a uniformly high silica content. Shipboard core descriptions indicate calcareous beds increase in number downsection but this result is not indicated on the log-derived $\mathrm{Ca}$ curve. The variability within the logs increases significantly in Unit III, because of the inhomogeneous nature of the turbidite beds. Oxides associated with clays in this unit $\left(\mathrm{FeO}^{*}, \mathrm{Al}_{2} \mathrm{O}_{3}, \mathrm{~K}_{2} \mathrm{O}\right.$, and $\left.\mathrm{TiO}_{2}\right)$ increase significantly as silica decreases. Silica is high again in the radiolarite of Unit IV. An increase in clay content is described from the sparse cores in Unit IV, but the log evidence does not support this.

\section{Site 802}

The processed natural gamma-ray logs from the geochemical tool string recorded at Hole 802A are displayed in Figure 7. The tuffaceous lithology of lithostratigraphic Unit II is divided into two subunits in the core: Subunit IIA contains zones of pelagic clay, and Subunit IIB is interlayered with redeposited calcareous claystone and chalk. The claystone within Subunit IIB increases in total proportion downsection, as reflected in $\mathrm{K}$ values. The cyclicity seen on the total gammaray $\log$ probably reflects the volcaniclastic turbidites described by the shipboard sedimentologist (Shipboard Scientific Party, 1990b).

The oxide weight fractions for Hole 802A and discrete carbonate core analyses are shown in Figure 8 . The $\mathrm{CaCO}_{3}$ core measurements agree well with the $\mathrm{Ca} \log$ measurements. The boundary between the tuff of Unit II and the chalk of Unit III is marked by a sharp increase in carbonate values and by a decrease in the values and variability in the $\mathrm{FeO}^{*}$ and $\mathrm{TiO}_{2}$ logs.

\section{SUMMARY AND CONCLUSIONS}

The reprocessing of natural gamma-ray logs improves the measurements obtained in the field by incorporating hole-size corrections and better calibrations of Th, U, and K. Geochemical logs, converted to elemental and oxide measurements, compare well with the overall trend of the core data. Discrepancies between $\mathrm{Al}_{2} \mathrm{O}_{3}$ and $\mathrm{SiO}_{2}$ core and $\log$ values are the result of selective sampling of silica-rich lithologies for analysis and possible mud caking. When core data are missing or sparse, the reprocessed logs provide an invaluable data set from which to interpret lithology (see Fisher et al., this volume). The general trends of $\mathrm{SiO}_{2}$ and $\mathrm{CaCO}_{3}$ values were found to be particularly useful in portraying increases or decreases in carbonate content. The $\mathrm{Al}_{2} \mathrm{O}_{3}, \mathrm{~K}_{2} \mathrm{O}$, and $\mathrm{FeO} *$ logs are useful in distinguishing relative amounts of clay.

\section{ACKNOWLEDGMENTS}

The authors would like to thank Susan Karl for supplying the shorebased XRF data. We would also like to thank Jennifer Tivy for her critical reviews of the manuscript and all her work in creating the final figures. 

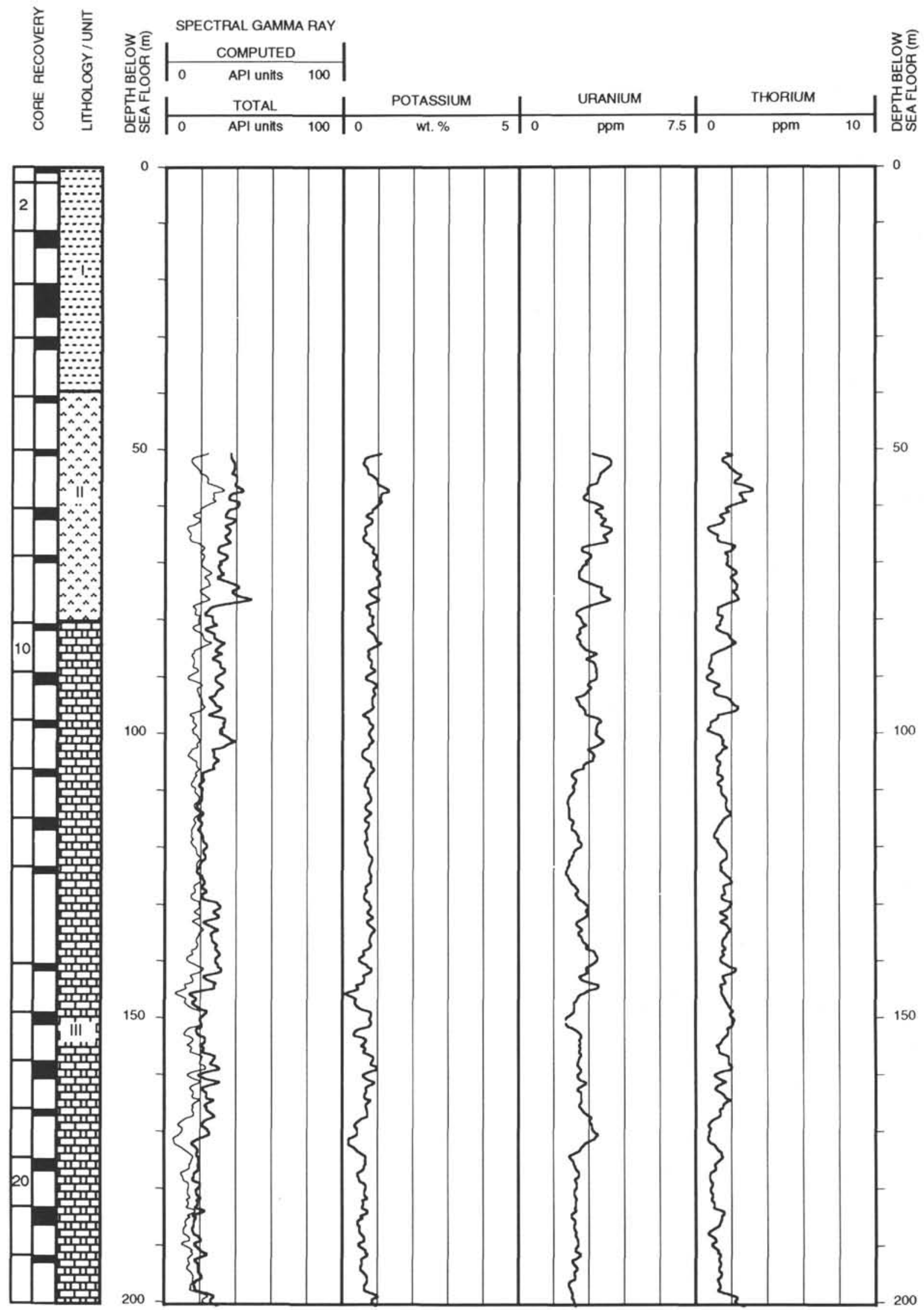

Figure 3. Processed natural gamma-ray data, Hole 800A. The symbols used in the lithologic legend are common to all the following figures. 

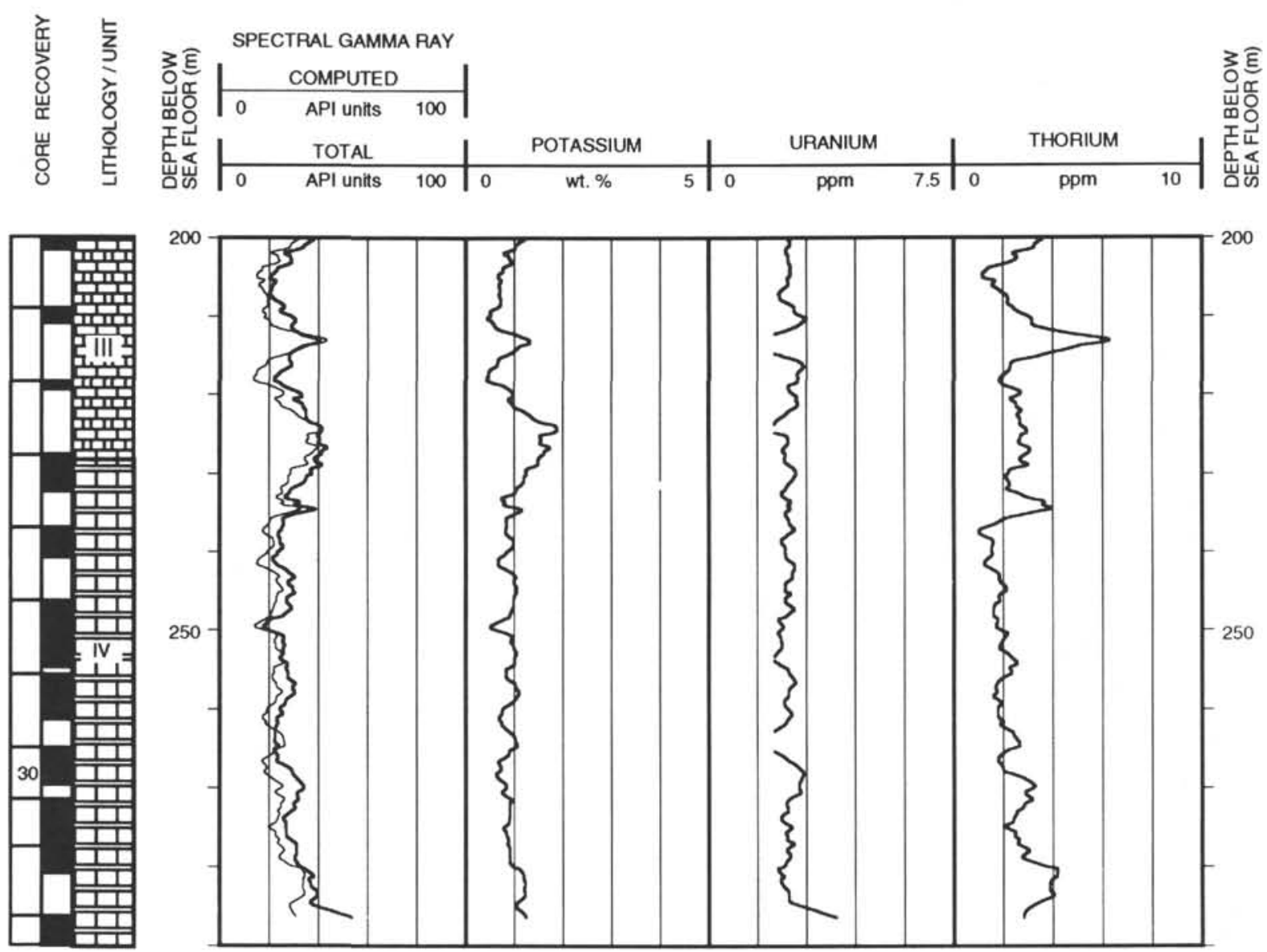

LEGEND OF SYMBOLS

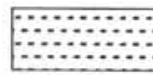

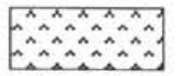

Brown chert and porcellanite

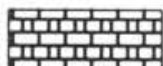

Gray radiolarian chert and limestone

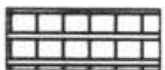

Volcaniclastics

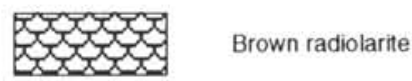

80200 Altemation of red radiolarite and claystone
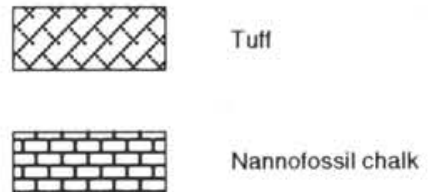

Figure 3 (continued). 


\section{REFERENCES}

Grau, J. A., and Schweitzer, J. S., 1989. Elemental concentrations from thermal neutron capture gamma-ray spectra in geological formations. Nucl. Geophys., 3:1-9.

Grau, J. A., Schweitzer, J. S., and Hertzog, R. C., 1990. Statistical uncertainties of elemental concentrations extracted from neutron-induced gamma-ray measurements. IEEE Trans. Nucl. Sci., 37:2175-2178.

Hertzog, R., Colson, L., Seeman, B., O'Brien, M., Scott, H., McKeon, D., Grau, J., Ellis, D., Schweitzer, J., Herron, M., 1987. Geochemical logging with spectrometry tools. Soc. Pet. Eng. Pap., 16792.

Lock, G. A., and Hoyer, W. A., 1971. Natural gamma-ray spectral logging. Log Analyst, 12:3-9.

Ruckebusch, G., 1983. A Kalman filtering approach to natural gamma ray spectroscopy in well logging. IEEE Trans. Autom. Control, AC-28:372-380.
Schwietzer, J. S., Grau, J. A., and Hertzog, R. C., 1988. Precision and accuracy of short-lived activation measurements for in situ geological analyses. $\boldsymbol{J}$. Trace Microprobe Tech., 6:437-451.

Scott, H. D., and Smith, M. P., 1973. The aluminum activation log. $\log$ Analyst, 14:3-12.

Shipboard Scientific Party, 1990a. Site 800. In Lancelot, Y., Larson, R., et al., Proc. ODP, Init. Repts., College Station, TX (Ocean Drilling Program), 33-89.

, 1990b. Site 802. In Lancelot, Y., Larson, R., et al., Proc. ODP, Init. Repts., College Station, TX (Ocean Drilling Program), 171-243.

Date of initial receipt: 26 June 1991

Date of acceptance: 18 November 1991

Ms 129B-149 


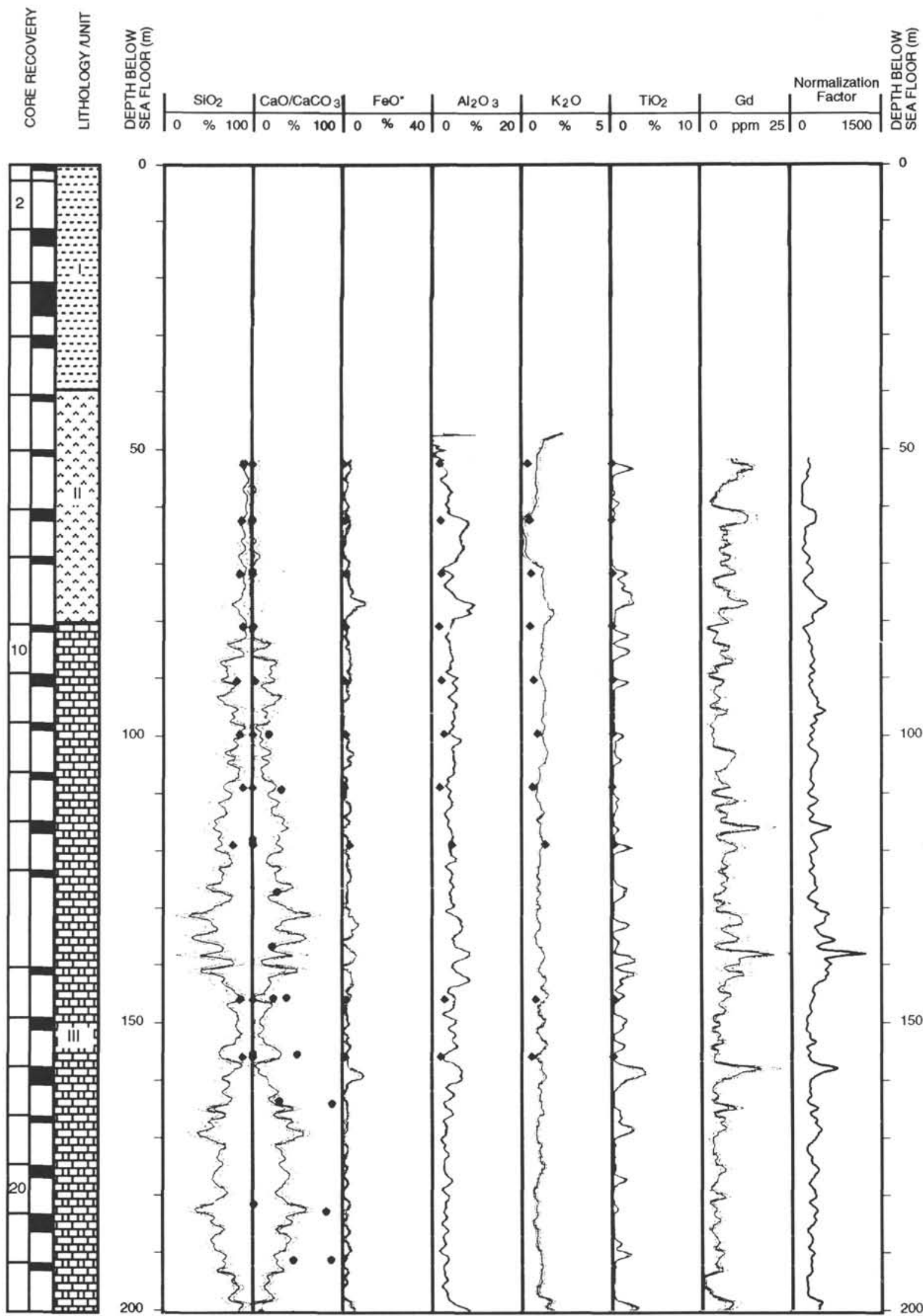

Figure 4. Estimates of calcium carbonate and major oxide-weight fractions from geochemical logs, Hole $800 \mathrm{~A}$. Solid circles represent carbonate values from core measurements (Shipboard Scientific Party, 1990a); diamonds represent XRF analysis from silica-rich cores (Karl and Karpoff, this volume). 

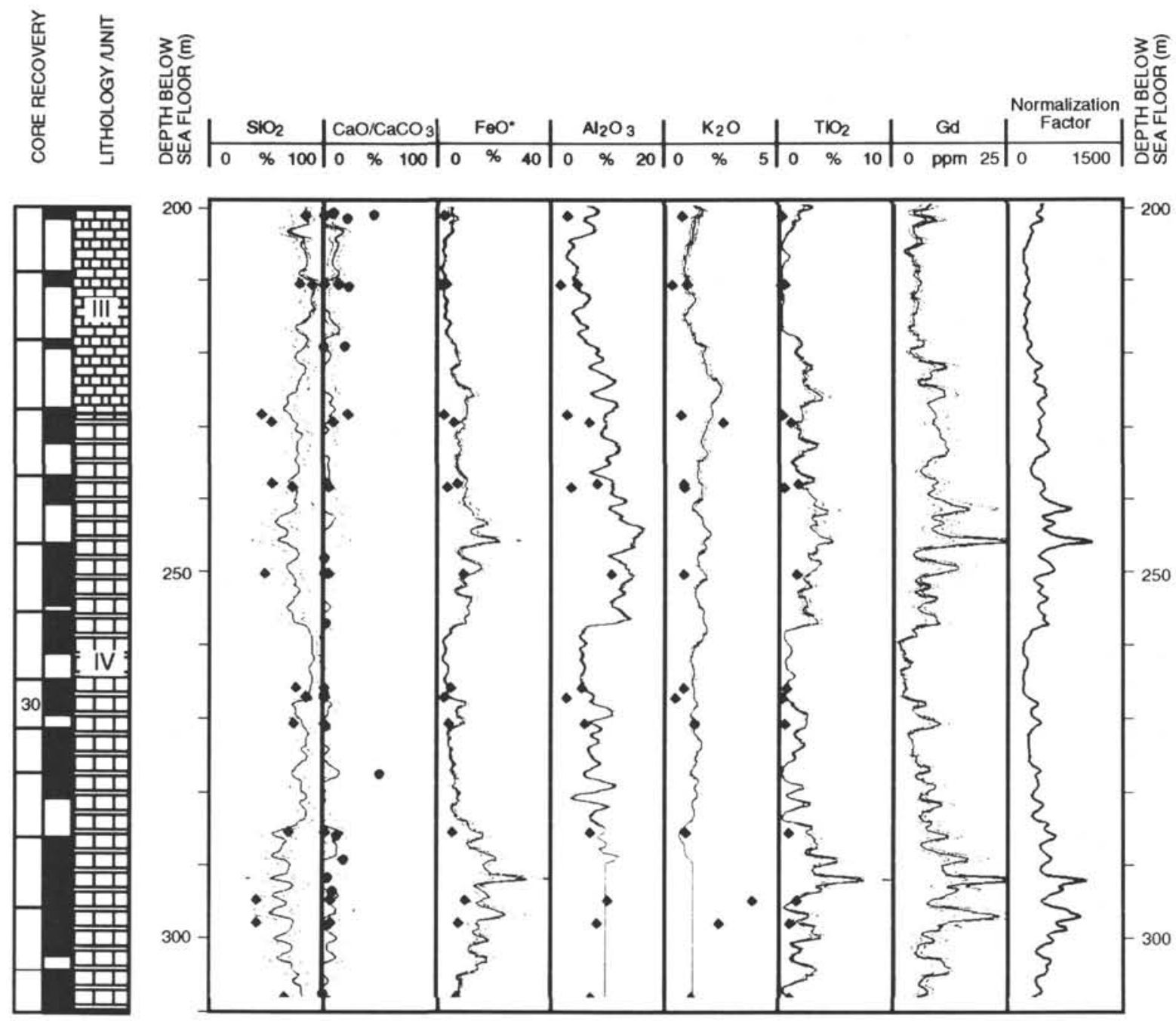

Figure 4 (continued). 

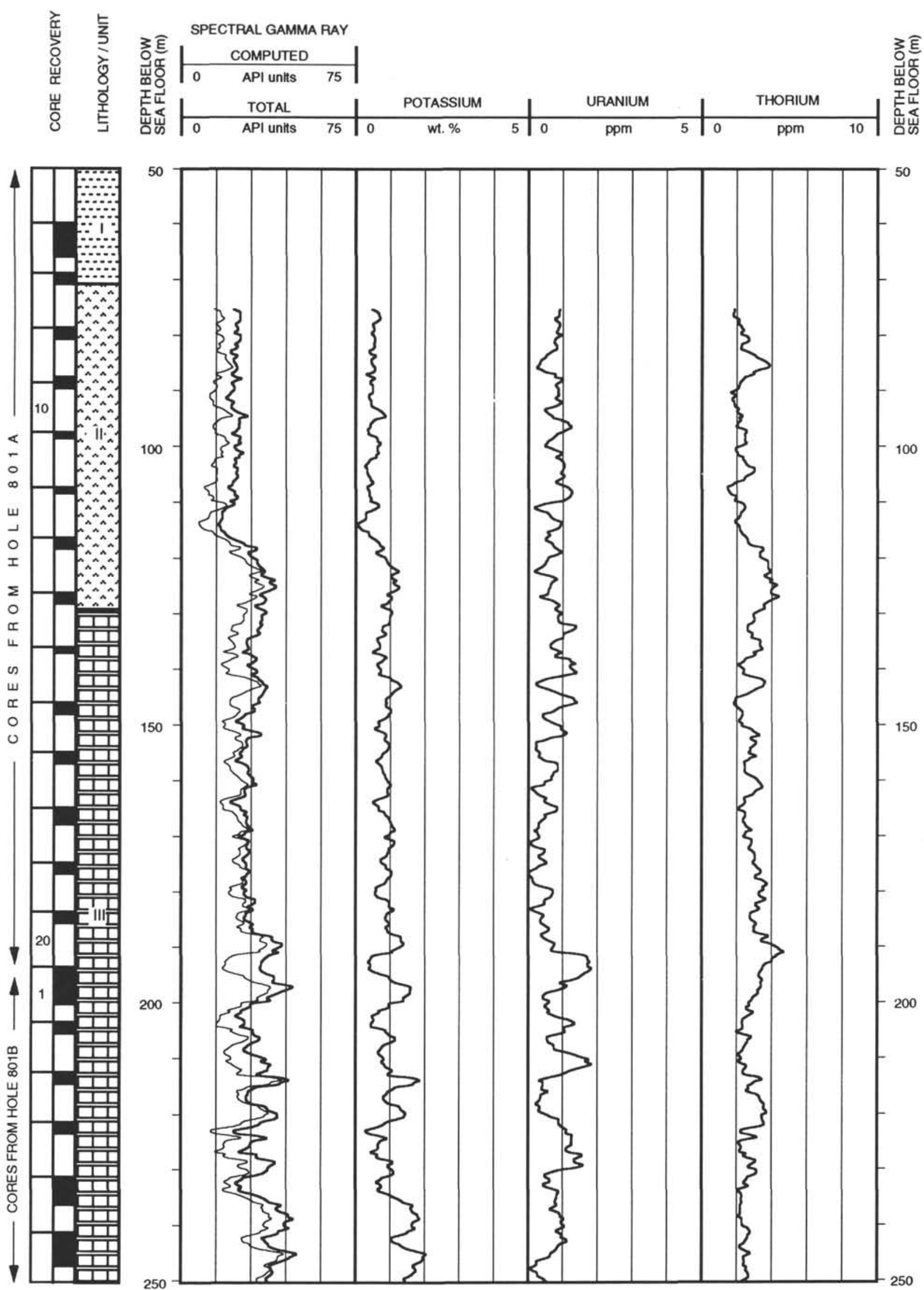

Figure 5. Processed natural gamma-ray data, Hole 801B. 

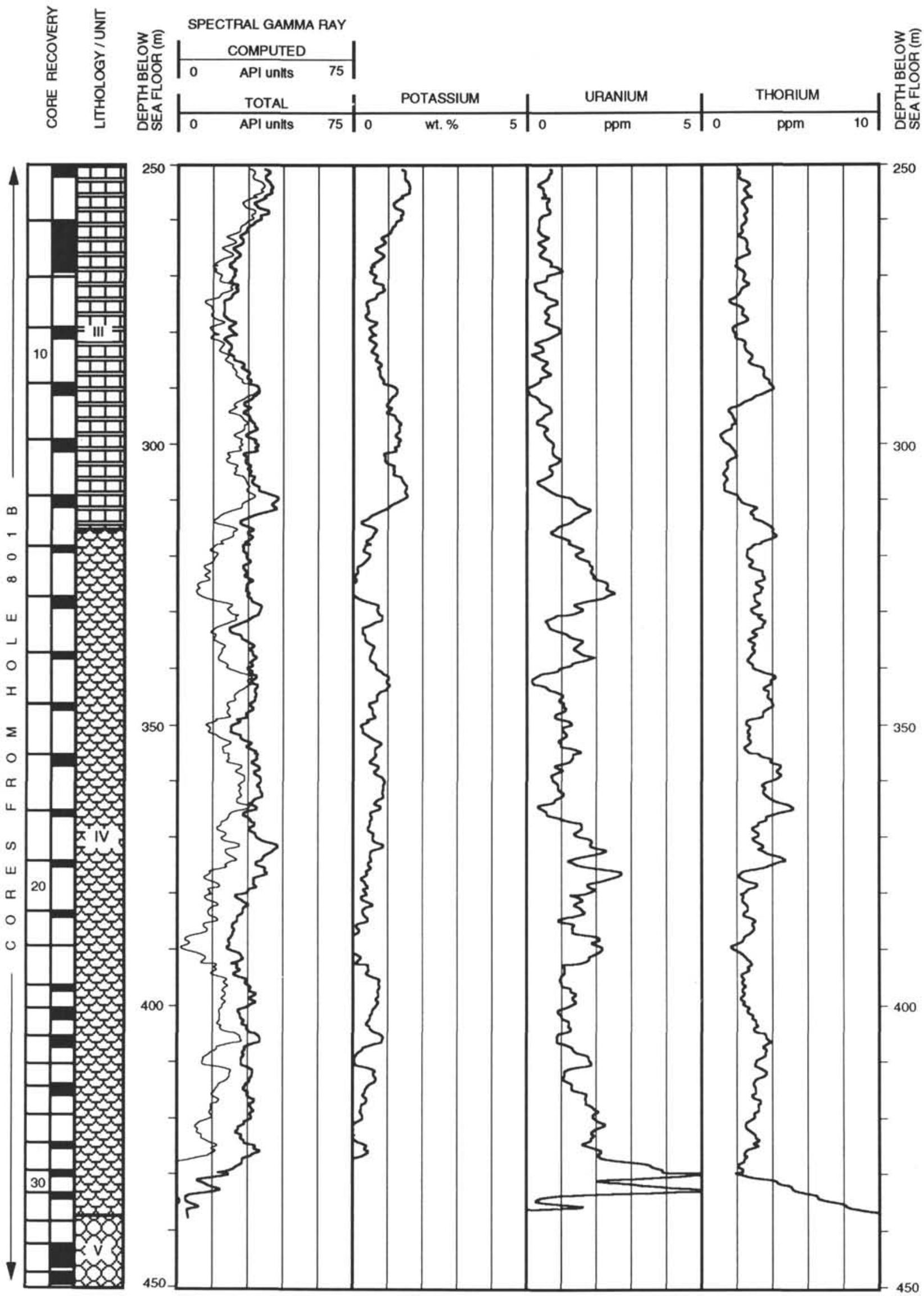

Figure 5 (continued). 

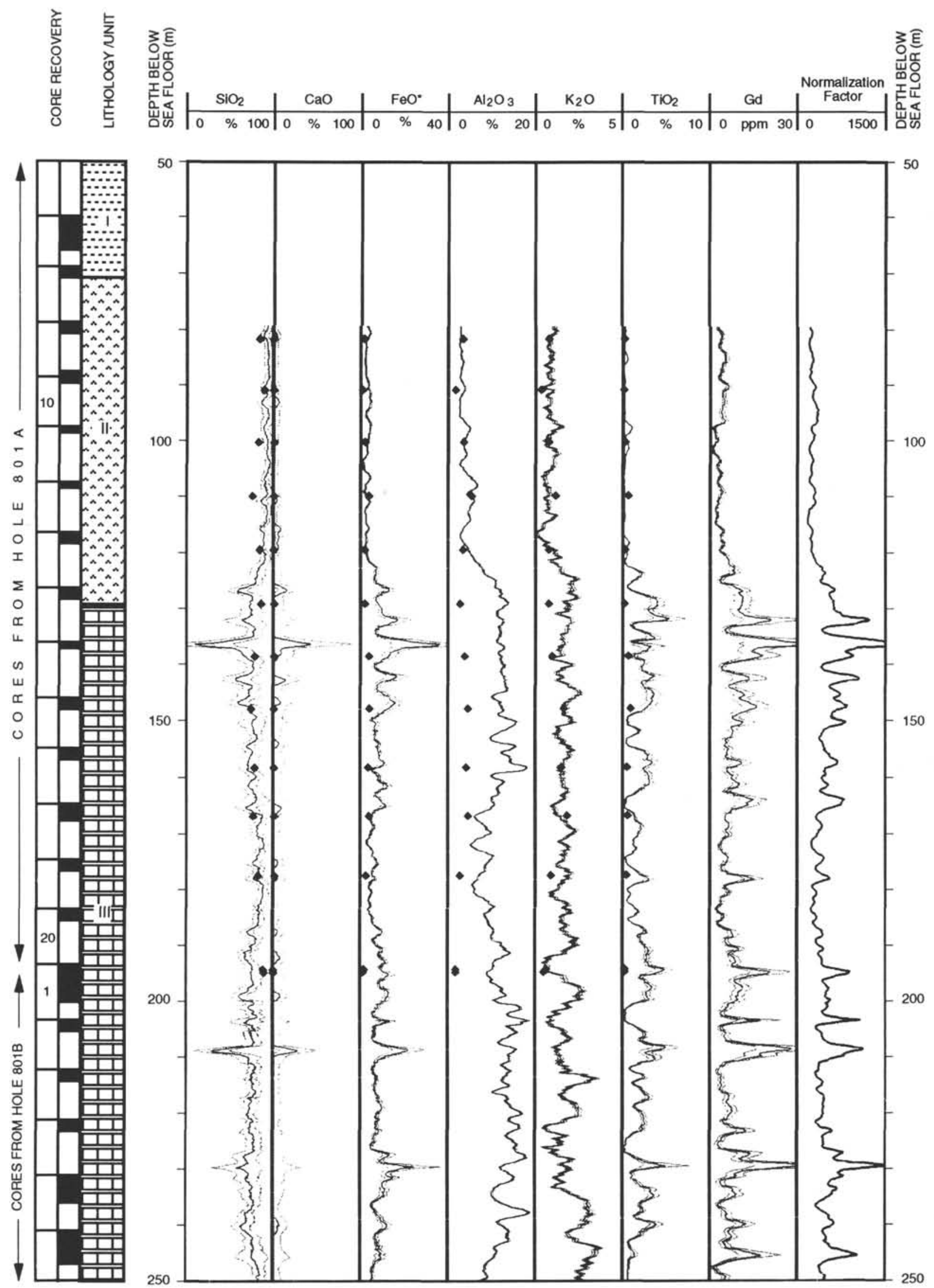

Figure 6. Major oxide-weight fractions from geochemical logs run in Hole 801B compared to XRF measurements (diamonds) of silica-rich lithologies (Karl and Karpoff, this volume). 


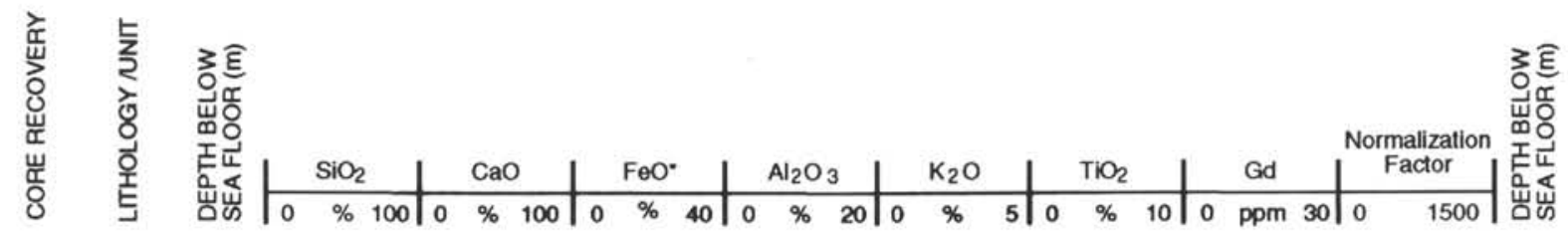
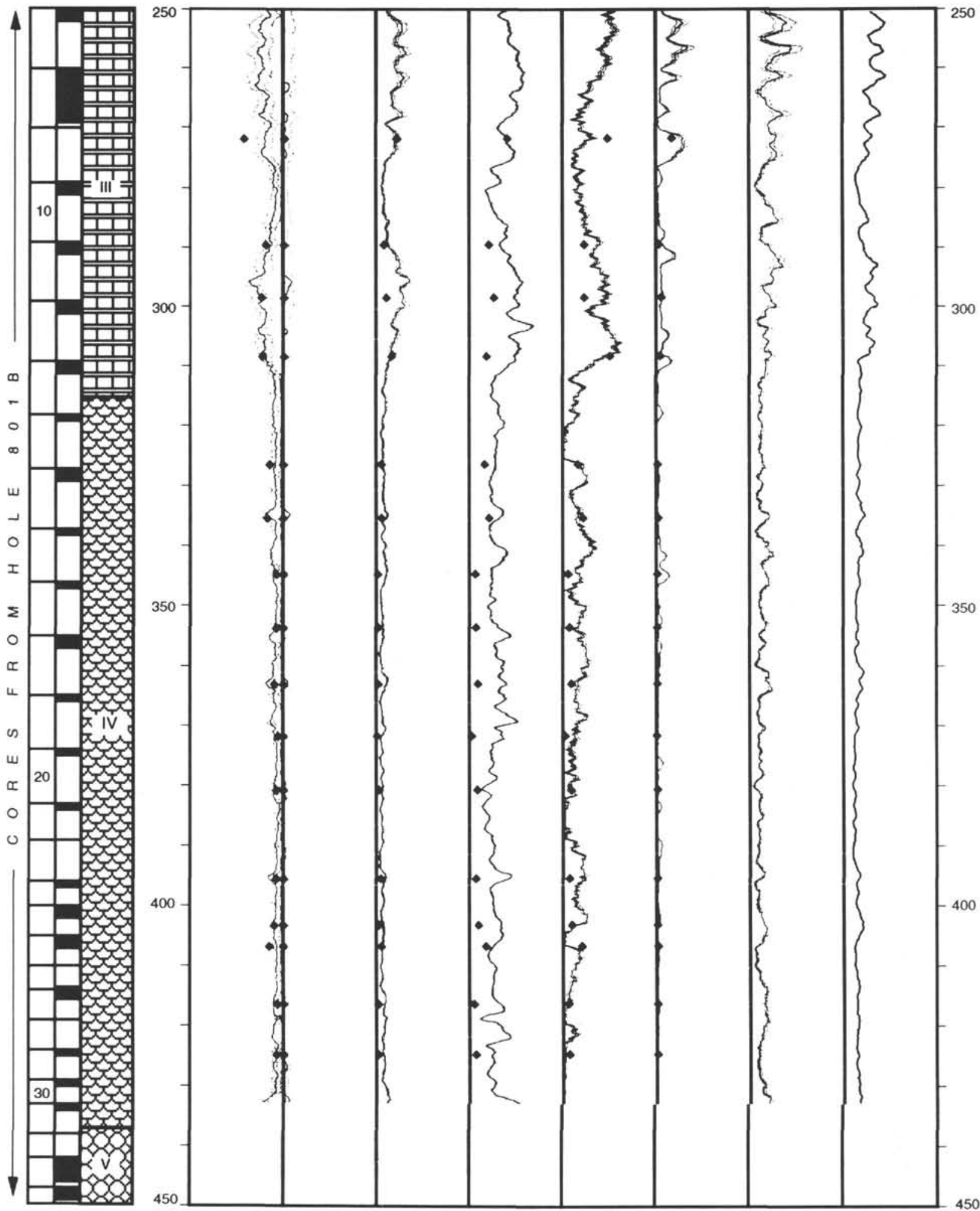

Figure 6 (continued). 

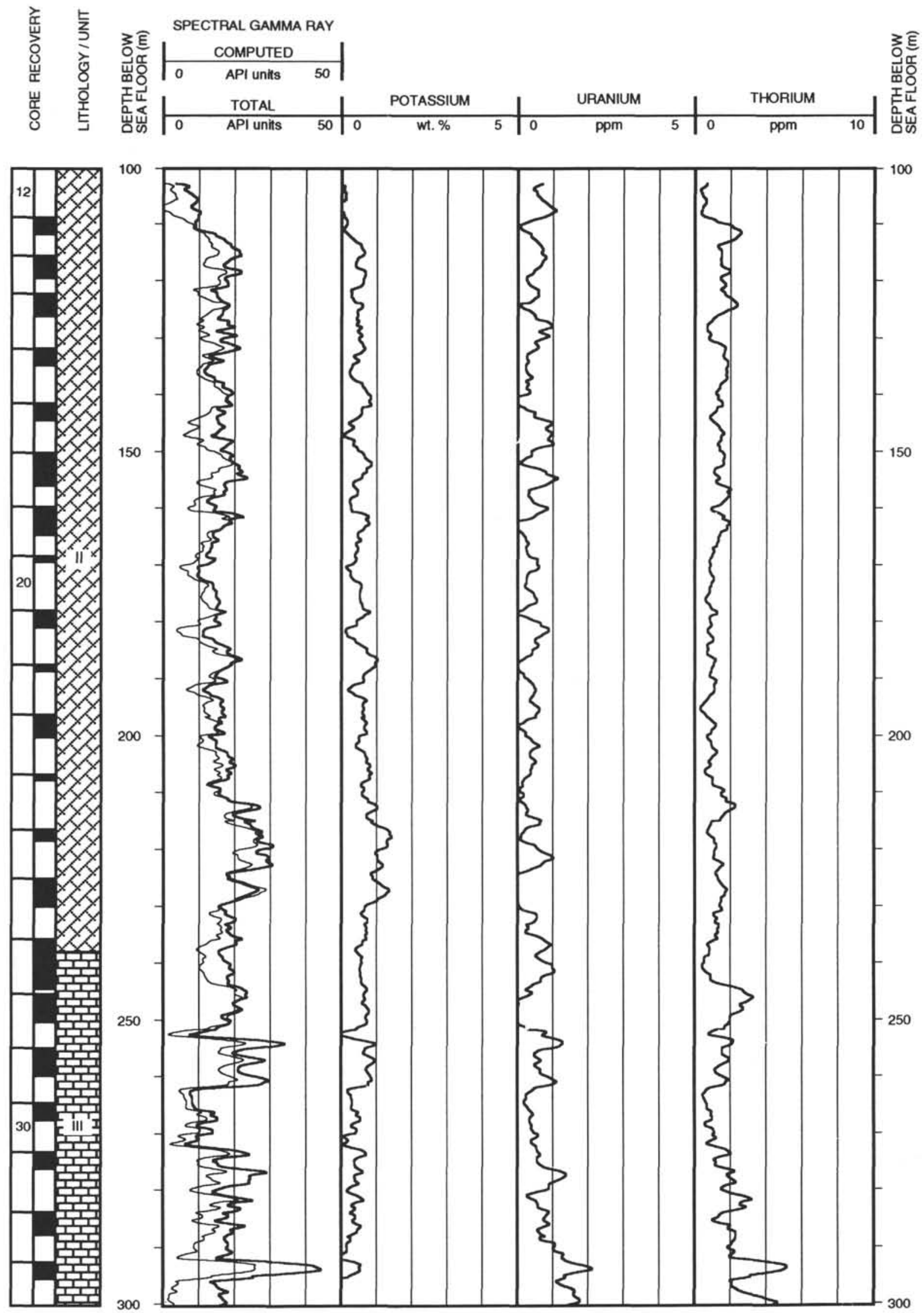

Figure 7. Processed natural gamma-ray data, Hole 802A. 

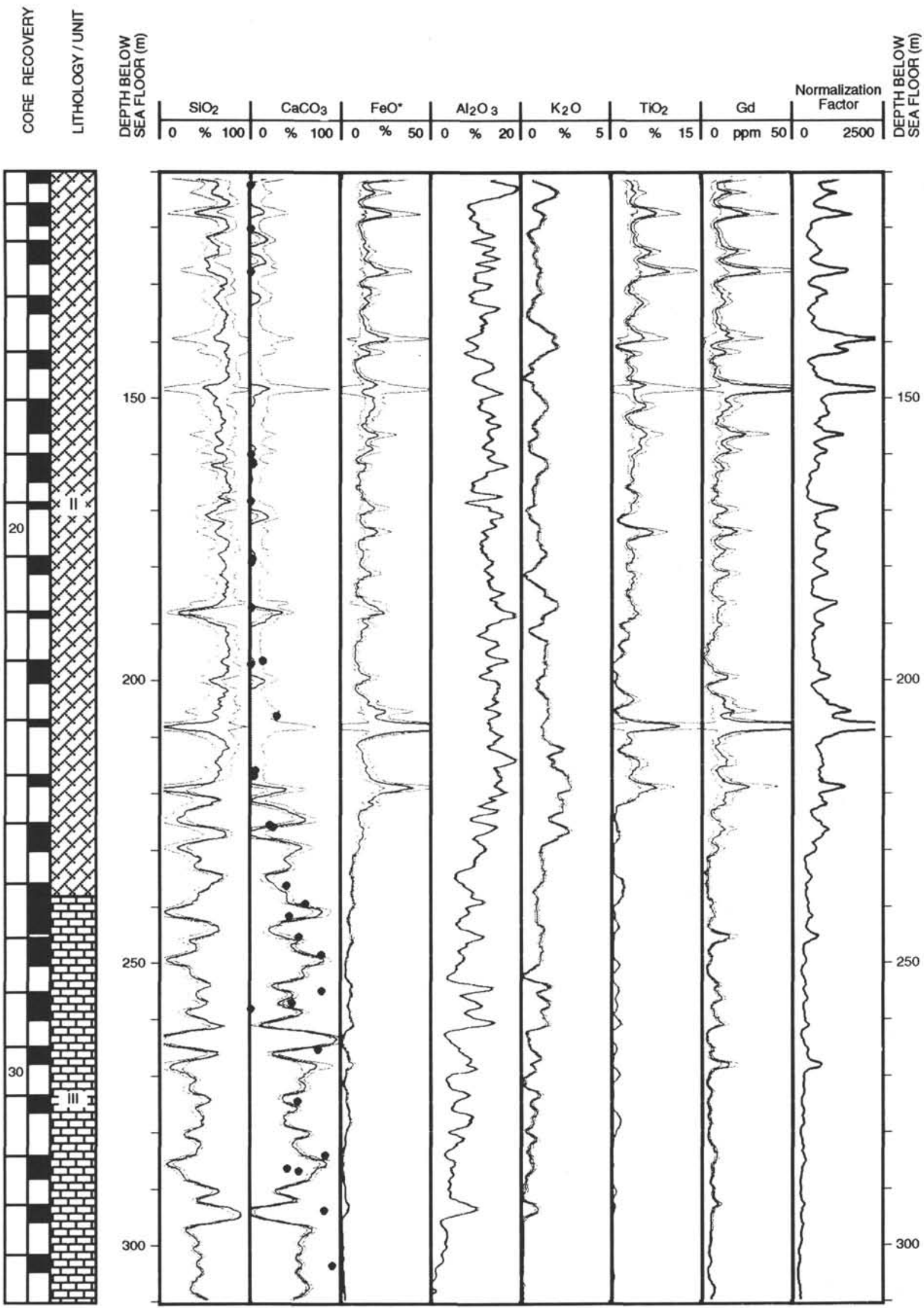

Figure 8. Estimates of the calcium carbonate and major oxide-weight fractions from geochemical logs run in Hole 802A compared to carbonate measurements (solid circles) from core (Shipboard Scientific Party, 1990b). 